\title{
Malaysian University Students' Attitudes towards Six Varieties of Accented Speech in English
}

\author{
Zainab Thamer Ahmed \\ Faculty of Modern Languages and Communication, Universiti Putra Malaysia \\ 43400 UPM Serdang, Selangor, Malaysia \\ Email: thamerzainab@yahoo.com \\ Ain Nadzimah Abdullah (Corresponding author) \\ Faculty of Modern Languages and Communication, Universiti Putra Malaysia \\ 43400 UPM Serdang, Selangor, Malaysia \\ E-mail: ain@fbmk.upm.edu.my \\ Chan Swee Heng \\ Faculty of Modern Languages and Communication, Universiti Putra Malaysia \\ 43400 UPM Serdang, Selangor, Malaysia \\ E-mail: shchan@fbmk.upm.edu.my
}

Doi:10.7575/aiac.alls.v.5n.5p.181

Received: 20/07/2014

URL: http://dx.doi.org/10.7575/aiac.alls.v.5n.5p.181

Accepted: 08/08/2014

\begin{abstract}
Previous language attitude studies indicated that in many countries all over the world, English language learners perceived native accents either American or British, more positively than the non-native accents such as the Japanese, Korean, and Austrian accents. However, in Malaysia it is still unclear which accent Malaysian learners of English tend to perceive more positively (Pillai 2009). The verbal-guise technique and accent recognition item were adopted as indirect and direct instruments in gathering data to obtain data to clarify the inquiry. The sample includes 120 Malaysian university students and they were immersed in several speech accent situations to elicit feedback on their perceptions. Essentially two research questions are addressed: 1) What are Malaysian university students' attitudes toward native and non-native English accents? 2) How familiar are students with accents? The results indicated that the students had a bias towards in-group accent, meaning that they evaluated non-native lecturers' accents more positively. These results supported the 'social identity theory' consistent with many previous language attitude studies of this nature. The Malaysian students were seen to be able to distinguish between native and non-native accents although there was much confusion between British and American accents.
\end{abstract}

Keywords: Accent; Attitudes; English Language Learners; Native; Non-Native Speakers.

\section{Introduction}

In Malaysia, different varieties of English accents are spoken because Malaysia is a multilingual and a multiethnic country. According to Pillai (2008) "English in Malaysia is spoken in a multitude of accents characterizing different ethnic and socio-economic groups, education, language and geographical backgrounds (e.g. East and West Malaysia)" (p.42). Moreover, English accents in Malaysia can be varied or scaled from marked and heavily marked, "Acromesolect", and "Mesolect" to less marked "Acrolect" accents because of the linguistic diversity, the different social classes, and the different levels of education (Gill, 1999). Similarly, Gill (2002) noted that "there is a continuum of accents in Malaysia ranging from more "unmarked" accents to strongly "marked" ethnic accents (p.64).

In the case of Malaysians, they tend to accent-switch depending on the context. According to Pillai (2008) it is also not unusual for Malaysians to accent-switch according to context which may be to construct a national identity, to express sense of belonging, solidarity, intimacy, and sometimes to make other people understand what they are trying to say, especially foreigners (p.42).

In Malaysian universities, different English accents are being spoken by different lecturers such as Malay, MalaysianChinese, and Malaysian-Indian. In addition, foreign lecturers are employed by universities and they speak English with different accents. As a result, students contend with both local and foreign accents in their classrooms, giving rise to possible difficulties in understanding their lecturers' accent. Previous language attitude studies indicated that university students are critical of foreign accents (Bresnahan, Ohashi, Nebashi, Liu, and Shearman, 2002). The situation could be such that "students often complain to their parents and to university administrators about having to take courses with foreign lecturers whom they find difficult to understand" (Bresnahan, Ohashi, Nebashi, Liu, and Shearman, 2002, p.172). 
However, in a study conducted by Pillai (2009) at University of Malaya among 90 undergraduate students, she found that there is no strong preference for all varieties of English accents (British, American nor for the local Malaysian variety). On another level, White and $\mathrm{Li}$ (1991) pointed out that "listeners who have difficulty in understanding a speaker are likely to experience negative affect" (p.111). At present, it is still indeterminate as to how Malaysian university students react to their lecturers' accents. As such, the present study seeks to add to the knowledge base in this area. In this study, 120 Malaysian undergraduate student's attitudes toward six accented speech of native and non-native varieties of speakers of English (American, Iraqi, British, Malaysian-Chinese, Malay, and Malaysian-Indian) are explored.

\section{Attitudes toward Language and Accent}

Language attitude studies have a very wealthy history that extends across numerous decades and cross disciplinary social science studies, and have substantially contributed to the development of the field of sociolinguistics (Ryan and Giles, 1982). Language attitude studies showed that language is a powerful social force that does more than convey intended referential information (Cargile 2000). Listeners tend to respond to linguistic and paralinguistic variations in messages as though they indicate personal and social characteristics of the speaker (Cargile and Giles ,1998). Cargile (2000) explained this by saying that "an American may think that a stranger is "cultured" and "refined" simply because his or her accent is recognized as British" (p.165). Cargile also illustrated that "such beliefs about language use can bias social interaction and often in that context when significant social decision-making is required, language attitudes represent significant communicative phenomena to investigate" (p.165).

Basically, language attitude studies focus on the social consequences of numerous language behaviours. For instance, scholars have mapped both the behavioural and the evaluative reactions of listeners to variations in speech style, speech rate, gender linked language, voice type, and code-switching. Accent is the most studied of all language behaviours because it is considered the most socially significant (Cargile ,2000). Therefore, many studies were conducted to find out whether accents have an influence on listeners' attitudes toward speakers or not. Interestingly, the results of these studies confirmed that accents have a great impact on listeners' attitudes or perceptions toward speakers (Butler, 2003).

Accent can be defined as a certain form of language spoken by a subgroup of speakers of that language which is defined by phonological features (Holmes, 1992, p.147). The terms accent and dialect often overlap and are used interchangeably. Hughes and Trudgill (2003) distinguished the terms dialect and accent by saying that "dialect refers to varieties distinguished from each other by differences of grammar and vocabulary, while "accent refers only to varieties of pronunciation" (p.3). In addition, a difference in the accent with which a language is spoken seems to be seen mainly as regional, social class, and ethnic differences. According to Ryan and Bulik (1982) variations in the accent with which a language is spoken tend to be viewed primarily as regional (e.g. Southern American vs. Northern American), social class (e.g. upper vs. middle vs. working class), or ethnic (e.g. Black English or Spanish-accented English vs. Standard American) (p.51).

\section{Standard versus non-standard accents}

It is generally believed that the level of prestige accorded to language accent variety is heavily influenced by two important factors, which are social structure and cultural value systems (Ryan \& Giles, 1982).

Studies by this context, Wilson and Bayard (1992) had compared New Zealand listeners' judgments of New Zealand, Canadian, Australian, British accented English, French-accented English, and Anglo American judgments of German and American accents.

The results generally indicated that most accents can be classified by the degree to which they are considered "standard" or "non-standard" within a particular community. Fishman (1971) distinguished between standard and nonstandard accent by saying that "a standard variety is that most often associated with status, the media, and power, whereas a nonstandard variety is one that is often associated with a lower level of socioeconomic success" (p.25). Furthermore, Richards and Platt (1992) defined the non-standard variety as "a spoken or written variety which is not accorded the highest prestige and which differs in terms of pronunciation, grammar or vocabulary from the standard (p.248). Later, Bex and Watts (1999) defined the standard variety as "the variety of a language based on the speech and writing of educated speakers and which has the highest degree of respect in a particular speech community" (p.7).

Generally, perceptions towards nonstandard accents were negative. The negative perception could also be linked to region. Region also plays an important role in the demarcation of standard or non-standard varieties. For example, Lippi-Green (1997) explained that Southern United States English and New York English are obviously varieties being discriminated against and are always evaluated less favorably in terms of 'correctness'.

Milory (2001) analyzed that the negative ratings of southern US speech and concluded that a correlation could exist between region and poverty that could lead to the discrimination. . However, Fought (2002) stated that perceptions towards varieties of southern US English is possibly prejudiced unjustifiably by links to African-American Vernacular English (AAVE).

Thus, a difference in accent with which a language is spoken can also be viewed as regional, belonging to a particular social class, and may also be ethnically defined. Ryan and Bulik (1982) for example illustrated regional difference as in Southern American and Northern American, while social class can be indicated as. Upper and Middle and working class variations. Ethnicity as a marker as can be manifested in Black English, Spanish accented English or New York 
English. Transcending the variations, is a perceived standard American accented English or standard British accented English.

\section{Accents and Different Traits}

Since accents can be classified by the degree to which they are considered "standard" and "non-standard". Usually, standard and non-standard accents can be rated differently based on different traits such as solidarity (or social attractiveness) (e.g., friendly, trustworthy, kind), status (or competence) (e.g., intelligent), dynamism (e.g., strong/weak), and personal integrity (e.g. helpfulness) (Ryan \& Giles, 1982).

Many language attitude studies have been conducted to investigate listeners' attitudes toward standard and non-standard accents in relation to different traits. The results indicated that the listeners rated the standard accents more favorably in terms of 'status', 'competence', and 'intelligence' dimensions while the non-standard accents are rated less favorably on these same dimensions. For instance, Ryan, Hewstone, and Giles (1984) found that the speakers who speak with standard accent were evaluated highly on traits related to competence, intelligence, and social status, whereas the speakers who speak with non-standard accent were evaluated less favorably on these same traits, even by judges who themselves speak with a non-standard accent.

On the other hand, numerous studies have shown that the speakers who speak with non-standard accent are evaluated or judged along traits related to solidarity, kindness, integrity, and overall attractiveness, they are rated much more favorably compared to the speakers with standard accent, and are sometimes being rated as more kind and attractive especially by listeners with a non-standard accent (Cargile \& Giles, 1998). For instance, Cheyne (1970) investigated Scottish subjects' attitudes toward different English accents. The researcher found that Scottish subjects tend to evaluate Scottish regional accents lower on status trait, but higher on solidarity trait than English regional accents.

In their study, Giles and Powesland (1975) found that listeners tend to perceive speakers who use regional accents as more likeable and more attractive (high solidarity) than those speakers who use standard accents. On the other hand, these particular evaluations are affected by many other variables such as the context in which speech take place, and the perceived socio-economic status of the speakers. For instance, Creber and Giles (1983) used RP and welsh-accented English to investigate the interaction between accent and context. They found that the standard speaker (RP) is upgraded on status variables especially in a formal context, whereas the non-standard speaker (Welsh) is downgraded on the same variables.

Basically, when non-regional accents or prestigious accents are evaluated by listeners in relation to competence trait they are usually perceived to be more competent. For instance, a study which was conducted by Giles (1971) investigated British people reactions' to RP, South Welsh and Somerset accents along different traits. The results indicated that RP was rated highly in terms of competence; South Welsh and Somerset were rated more favorably on integrity and attractiveness.

Various language attitude studies indicated that people tend to prefer languages or dialects spoken by historically powerful groups, especially when it comes to status-related qualities (Lindemann, 2003). Particularly, Giles (1970) investigated British secondary school children reactions toward different accents, including the non-regional RP (Received Pronunciation), Irish, German and West Indian accents. The results indicated that RP was rated most favorably in terms of status, aesthetic quality and communicative content (a measure of the perceived ease of interaction with the speaker), regional accents such as South Welsh and Somerset were in the middle ranks, and urban accents such as Cockney and Birmingham were at or near the bottom of the scale.

Hiraga (2005) investigated British attitudes towards six varieties of English dialects in Britain and the USA in order to re-examine Giles's (1970) findings. The researcher found that British listeners tend to favor RP accent above all American varieties, they also tend to favor only the 'prestigious' varieties such as the American standard (Network American) rather than British regional varieties.

Many studies in an independent sphere of inquiry have indicated that people prefer, and judge more favorably, members of their own social ingroups, compared to outgroup members ( Cargile \& Giles, 1998). Similarly, Abrams and Hogg (1987) conducted a study in Scotland to investigate secondary school students' attitudes towards Dundee, Glasgow, and Received Pronunciation (RP) English accents. The researchers made three conditions each possible pairing in formal and informal contexts using the matched-guise technique as a methodology to record the three accents (Dundee, Glasgow, and RP). The results indicated that the in-group accents were judged positively and the out-group negatively. Therefore, Glasgow accents were judged or evaluated negatively when compared with Dundee accents, but positively when compared with RP. In addition, Abrams and Hogg found that levels of ingroup favoritism interrelated positively with measures of identification with Scotland.

However, Grondelaers, Hout, and Steegs (2010) conducted a study to investigate the Dutch people attitudes toward Dutch regional accents and standard accent in the Netherlands. The results indicated that although the participants were able to identify all the regional and the non-regional accents. But, the results indicated that there is no in-group favoritism in the evaluations, not even among speakers of the high prestige accent (the Rand accent), who are famous to be proud of their own speech. In addition to that, the results have indicated that accent attitudes in the Netherlands appear to be nationwide experiential constructs, determining social meaning on the national level rather than on the 
regional level. So, the results in this particular study are somehow contradicting with the previous studies because it was found that there is no in-group favoritism.

Language attitude studies suggested that when non-native speakers are evaluated by listeners in relation to 'competence' trait they are usually perceived to be less competent than the native speakers of English. But, when the evaluations come to 'solidarity' trait the results is very different because listeners tend to express a clear preference for the non-native speakers. In particular, McKenzie (2010) investigated the attitudes of 558 Japanese university students towards six native and non-native varieties of English accents that includes two British accents (Glasgow vernacular speech, and Glasgow Standard English), two American accents (Southern US English Alabama, and Midwest US English), and two Japanese non-native English speakers, one speaker spoke moderately-accented Japanese English, and the other one spoke heavily-accented Japanese English. The researcher adopted the verbal-guise technique as a methodology because the researcher could not find one single speaker who could convincingly produce all six varieties of English accents. The results indicated that Japanese university students rated the native accents more favorable than Japanese English accents in terms of 'competence' trait. On the other hand, the results indicated the non-native Japanese accents were rated more favorable in terms of solidarity trait.

\section{Research Questions}

- This study addressed the following research questions: What are Malaysian university students' attitudes toward lecturers' native and non-native English accents?

\section{- Are the Malaysian students able to distinguish between native and non-native varieties of English accents? \\ 6. Method}

The following section provides the methods that were used for this particular study.

\subsection{Participants}

One hundred and twenty undergraduate students from Putra University of Malaysia (UPM), which is located in Serdang, Selangor, Malaysia, participated in this study. They were all Malaysians from the three major Malaysian ethnic groups: Malay, Malaysian-Chinese and Malaysian-Indian. Forty seven were Malay, 39 were Malaysian-Chinese, and 34 were Malaysian- Indian. All the undergraduate students who participated in this study were in year one and they were taking the university English proficiency course, Oral Interaction Skills (BBI2420).

\subsection{Verbal-guise Technique and Justification}

The purpose of the research instrument is to measure indirectly, the language attitudes of the participants towards six varieties of accented speech of lecturers. McKenzie (2010) mentioned that "an indirect approach to researching attitudes most often involves the aim of the study being concealed from the informants, in order to penetrate below the level of conscious awareness or behind the individual's social facade" (p.86).

Although most previous language attitude studies employed "the matched-guise technique", in this case, the present study employed the verbal-guise technique because firstly, it was impossible to find one single speaker who could produce all the six varieties of English accents. Similarly, McKenzie (2008) pointed out that "from a practical point of view, it would prove impossible to find a single speaker who could convincingly produce all six varieties of English" (68). Also, Garrett, Coupland, and Williams (2003) stated that "the verbal guise technique is used out of necessity, since it is not always possible to find a single person who can completely produce all varieties required for the study" (p.53).

Secondly, it was believed that the usage of the spontaneous speech was more valid than a read pre-prepared text which is used in the matched-guise technique (McKenzie, 2010). Likewise, Van Bezooijen and Gooskens (1997) suggested that the geographic origin of the speaker is easier to recognize for listeners when the speech sample is spontaneous rather than when the speaker is reading aloud from a given text, as spontaneous speech can contain a wider range of cues related to the speaker's geographic origin and can also vary lexically, syntactically or morphologically. Additionally, Alford and Strother (1990) indicated that "the verbal guise technique is good to overcome "a feigned accent" of the matched guise technique" (p.486).

The verbal-guise technique involves participants listening to recordings of speech from a series of speakers e.g. lecturers and interviewers (McKenzie, 2008). After that, participants are requested to evaluate each speaker, usually on a semantic-differential scale (e.g. fluent/ not fluent, clear/ unclear, confident/ not confident, and friendly/unfriendly) regarding a number of different traits.

This study adapted eight semantic-differential scales (See Table1). The choice of the semantic-differential scales were based on the previous language attitude studies involving non-native participants (refer to Chiba, Matsuura, and Yamamoto, 1995; Kim, 2007; Matsuura, Chiba, and Fujieda, 1999; McKenzie, 2010; Zahn and Hopper, 1985). 
Table 1. Verbal-guise-technique: the semantic-differential scales adapted for this study

\begin{tabular}{|c|c|c|c|c|c|c|}
\hline $\begin{array}{l}\text { Not clear at } \\
\text { all }\end{array}$ & 1 & 2 & 3 & 4 & 5 & Very clear \\
\hline $\begin{array}{l}\text { Not } \\
\text { intelligent at } \\
\text { all }\end{array}$ & 1 & 2 & 3 & 4 & 5 & $\begin{array}{l}\text { Very } \\
\text { intelligent }\end{array}$ \\
\hline $\begin{array}{l}\text { Not } \\
\text { confident at } \\
\text { all }\end{array}$ & 1 & 2 & 3 & 4 & 5 & $\begin{array}{l}\text { Very } \\
\text { confident }\end{array}$ \\
\hline $\begin{array}{l}\text { Not friendly } \\
\text { at all }\end{array}$ & 1 & 2 & 3 & 4 & 5 & $\begin{array}{l}\text { Very } \\
\text { friendly }\end{array}$ \\
\hline $\begin{array}{l}\text { Not careful } \\
\text { at all }\end{array}$ & 1 & 2 & 3 & 4 & 5 & Very careful \\
\hline $\begin{array}{l}\text { Not familiar } \\
\text { at all }\end{array}$ & 1 & 2 & 3 & 4 & 5 & $\begin{array}{l}\text { Very } \\
\text { familiar }\end{array}$ \\
\hline $\begin{array}{l}\text { Not fluent at } \\
\text { all }\end{array}$ & 1 & 2 & 3 & 4 & 5 & Very fluent \\
\hline $\begin{array}{l}\text { Not } \\
\text { sophisticated } \\
\text { at all }\end{array}$ & 1 & 2 & 3 & 4 & 5 & $\begin{array}{l}\text { Very } \\
\text { sophisticated }\end{array}$ \\
\hline
\end{tabular}

\subsection{Reliability Test}

Reliability test was conducted to test the internal consistency of the semantic-differential scales which were adapted from previous studies for the purpose of this study. Results of the test are presented in Table 2 semantic-differential scales to measure attitude which was made up of eight different traits was found to be good reliabliability as the Cronbach's alpha (.874) is higher than the acceptable level (.70) (Reinard, 2006, p.121).

Table 2. Reliability Coefficient of study's semantic-differential scales

\begin{tabular}{clc}
\hline Instrument & No of scales & Cronbach's Alpha \\
\hline Attitude & 8 & .874 \\
\hline
\end{tabular}

\subsection{Accent recognition item}

The aim of this part of the research instrument is to determine whether the Malaysian university students are able to identify the different accents in the speech recordings correctly or not. It is very significant to include accent recognition item because it is wished that the answers will give information with regard to how precisely and constantly the participants can identify the speech varieties that were recorded for the reason of evaluation (McKenzie, 2010, p.88). Furthermore, as the study aims to investigate speech evaluation of second language learners who definitely have less exposure to varieties of English compared to native speakers of English (McKenzie, 2010, p.88). In addition, participants who cannot identify the speech varieties correctly they are likely to incorrectly identify the stimulus speech as a language or language variety with which they are more familiar and one which they relate with the misidentified variety of speech (McKenzie, 2010, p.88). So, accent recognition item was included in line to make the data collected in this study more simple to interpret.

So, in order to achieve this aim, the students were asked to listen to the recording of each speaker and then they were asked to identify the accent of each speaker. The students were given different choices in order to determine the accent of each speaker such as Malay, Malaysian-Indian, Malaysian-Chinese, British, American, and Iraqi. The accent identification question was adapted from Chiba, Matsuura, and Yamamoto's (1995) study.

\subsection{The Varieties of Accents Selected}

Six speech samples of six varieties of English accents were selected for this study. The researcher went to each lecturer's office in order to record the interview with the lecturers. The interviews were recorded in Sony voice recording device. In the recording of the interview, lecturers discussed about their favorite place in Malaysia. Each sample lasted for about two minutes. Four non-native varieties of English accents and two native varieties of English accents were chosen for the recording purpose; three of the recorded non-native varieties of English are spoken in Malaysia: Malay accent, Malaysian-Chinese accent, and Malaysian-Indian accent. The other one of the recorded nonnative varieties of English is Arabic accent which is spoken particularly in Iraq-Baghdad. The other two native varieties of English recorded are spoken in the United States and United Kingdom: Southern US English (Alabama) and East London accent (Essex). All speakers are lecturers at Universiti Putra Malaysia (UPM) except for the British and American. 


\section{Results and Analysis}

This section presents the results of this study with regard to Malaysian university students' attitudes toward accent in relation to different traits such as confidence, solidarity, and clarity. Also, this section presents the results of the students' familiarity with different varieties of English accents.

\subsection{Malaysian Students' Attitudes toward Native and Non-Native English Accents}

The results of this study indicated that the Malaysian university students tended to evaluate the four non-native lecturers' accents more positively than the two native lecturers' accents. Table 3 below shows that overall, the nonnative lecturers' accents were perceived positively by the students. On the other hand, Table 3 also shows that the Malaysian students viewed the British and the American accents less positively. The results of the paired sample t-test indicate that the there was a significant difference $p<0.05$ (Table 3). This means that the mean values for the non-native accent (3.6250) and that of, the native accent (1.4083) is significantly different.

Table 3. Means of total scores for students' evaluations of the native and non-native accent groups $(\mathrm{n}=120)$

\begin{tabular}{lccc}
\hline Item & Mean & Std deviation & P \\
Non-native accents & 3.6250 & 0.60893 & \\
Native accents & 1.4083 & 0.69204 & .000
\end{tabular}

Note: $p=0.05$

These results are supported by the "social identity theory" that was developed by Tajfel and Turner in $(1979,1986)$ which suggests that people will show a preference for the variety of language or accent that is associated with their most salient in-group. Many studies also supported this theory which showed that an accent different from one's own is an important indicator that signals that someone is viewed as different (refer to Ryan 1983; Giles et al. 1987; White and Lee 1991; Bresnahan and Kim 1993; Bresnahan, Ohashi, Nebashi, Liu, and Shearman 2002). Moreover, Tajfel and Turner $(1979,1986)$, the early theorists, maintained that "in-group identity is so compelling that even when people from different groups are interacting with each other as individuals apart from their group, they are likely to be thinking in terms of their most salient in-group identification from which self worth and esteem derive" (p.33).

The Malaysian students $(n=120)$ tended to evaluate the non-native speakers more positively than the native speakers likely because the students identified themselves more with 'non-native accents' and for this reason, they demonstrated accent loyalty towards it, and also the students evaluated the Iraqi speaker more positively than the native speakers because many Iraqis are living in Malaysia. These results are consistent with previous studies which indicated that people prefer, and judge more favourably, members of their own social in-groups rather than out-groups members (Cargile and Giles, 1998).

As well, Abrams and Hogg (1987) had also conducted a study in Scotland to investigate secondary school students' attitudes towards Dundee, Glasgow, and Received Pronunciation (RP) English accents. The results indicated that the ingroup accents were judged positively while the out-group was viewed negatively. Glasgow accent was judged or evaluated negatively when compared with Dundee accent. Glasgow accent however was judged, positively when compared with RP. In addition, Abrams and Hogg found that levels of in-group favouritism interrelated positively with measures of identification with that of Scotland's. Kim's (2007) study in Korea indicated that Korean university students showed positive attitudes toward the Chinese, Indian, Taiwanese, and Korean accented English.

Bresnahan, Ohashi, Nebashi, Liu, and Shearman (2002) illustrated that "when categorizing is salient, an individual will tend to differentiate between in-group and out-group as much as possible on as many dimensions as possible and this maximization of differences will tend to be negative for the out-group and favourable for the in-group (p.172). Similarly, in the present study when the students were asked to rate the native and the non-native lecturers based on stereotypical traits, they rated the four non-native lecturers more positively than the two native lecturers. On the other hand, the students rated all the lecturers (native and non-native) equally on two traits. The following sections present the results of each trait. Also, Table 4 shows the mean ratings, standard deviations (SD), and the results of the $t$-test of all eight traits for the six lecturers.

\subsection{Clarity}

In terms of "clarity", all the non-native accents (Malay, Malaysian-Chinese, Malaysian-Indian, and Iraqi accents) were rated highly, whereas all native accents (American and British) were rated less favourably on the same trait. The mean differences were shown to have highly significant differences $3.4181,3.0458,(p \prec 0.05)$ (see Table 4). A possible explanation for the favourable responses to clarity of the non-native speakers is that the students understand the nonnative accents more than the native accent as they are more familiar with the non-native accents.

\subsection{Intelligence}

The Malaysian students also perceived the non-native speakers as more intelligent than the native speakers based on accent. Highly significant differences were found in the results mean $=(3.4799,3.2750)(p \prec 0.05)$ (see Table 4). On the other hand, other language attitude studies suggested that when non-native speakers are judged or evaluated by listeners 
in relation to "intelligence" they are usually perceived to be less intelligent than the native speakers of English. Specifically, Nyquist, Abbott, Wulff, and Sprague (1991); Nelson (1991); Solomon (1991) investigated American students' attitudes towards the non-native accents of foreign-born teachers and instructors in the light of the increasing number of such instructors at American universities. The cited researchers found almost the same findings which indicate that teachers with foreign accents (non-native speakers) were perceived by the American students and their parents to be less intelligent compared to teachers without foreign accents. The results regarding the "intelligence" trait in this study contradicted previous language attitudes research as noted above. The participants in the previous studies were British native speakers of English.

\subsection{Confidence}

The results also indicated that the students evaluated the non-native speakers more positively than the native speakers in terms of confidence. Again highly significant differences were found in the results mean $=(3.7306,3.4799)(p<0.05)$ (see Table 4). The Malaysian students felt that non-native lecturers are more confident than the native lecturers.

\subsection{Friendliness}

The results indicated that the students rated the non-native lecturers more favourably than the native lecturers in terms of friendliness. Highly significant differences were found in the results mean $=(3.5090,3.2167)(p<0.05)$ (see Table 4). This particular result is consistent with McKenzie's (2008) study which indicated that the non-native Japanese accents were rated more favourably than the native English accents (American and British) in terms of solidarity or social attractiveness.

\subsection{Carefulness}

In relation to being careful, the students evaluated the non-native lecturers more favourably than the native speakers mean $=(3.5292,3.3458)(p<0.05)$. One possible explanation for this particular result is that when the non-native speakers speak in their second language, they tend to be extremely careful in their choice of language such as in vocabularies and grammar. The native speakers, on the other hand, speak naturally and spontaneously using vocabularies and grammar that they have acquire English as a first language since childhood, which may be unfamiliar to non-native speakers.

\subsection{Familiarity}

With regard to familiarity, the students tended to be significantly familiar with the non-native lecturers' accents than the native lecturers' accents, mean $=(3.5979,3.2625)(p<0.05)$ (Table4). A possible explanation is that the students have enough exposure to the Malay, Malaysian-Indian, Malaysian-Chinese, and Iraqi accents since most of their lecturers use these accents and the students would have be attuned to the accents since childhood.

\subsection{Fluency and Sophisticated Traits}

The students evaluated both native and non-native lecturers equally in terms of fluency and sophisticated traits. The results did not indicate any significant differences in the responses to native and non-native accents of the lecturers $(p>0.05)$ (As shown in Table 4). When a person speaks with an accent, many things can be revealed from his or her accent such as regional, educational, and social backgrounds (Ryan and Giles, 1982). It seems that when the students were listening to the recordings they were able to identify that all the speakers are highly educated and all of them came from an educated class. Thus, the students evaluated them equally in terms of the traits investigated (see Table 4).

Table 4. Mean ratings and Standard Deviations of 4 non-native and 2 native English speakers on Eight Traits ( $\mathrm{n}=120)$

\begin{tabular}{|c|c|c|c|c|}
\hline $\begin{array}{l}\text { Items for the } 8 \\
\text { different traits }\end{array}$ & Mean & Std. Deviation & $\mathrm{t}$ & $\mathrm{P}$ \\
\hline Clarity & & & $-5.690 *$ & .000 \\
\hline $\begin{array}{l}\text { Non-native } \\
\text { speakers }\end{array}$ & 3.4181 & .55076 & & \\
\hline Native speakers & 3.0458 & .64494 & & \\
\hline Intelligence & & & $-2.977^{*}$ & .004 \\
\hline $\begin{array}{l}\text { Non-native } \\
\text { speakers }\end{array}$ & 3.4799 & .61863 & & \\
\hline Native speakers & 3.2750 & .68859 & & \\
\hline Confidence & & & $-2.079 *$ & .040 \\
\hline $\begin{array}{l}\text { Non-native } \\
\text { speakers }\end{array}$ & 3.7306 & 1.55305 & & \\
\hline Native speakers & 3.4208 & .84265 & & \\
\hline Friendliness & & & $-5.117 *$ & .000 \\
\hline $\begin{array}{l}\text { Non-native } \\
\text { speakers }\end{array}$ & 3.5090 & .61464 & & \\
\hline Native speakers & 3.2167 & .68824 & & \\
\hline Carefulness & & & $-2.856^{*}$ & .005 \\
\hline $\begin{array}{l}\text { Non-native } \\
\text { speakers }\end{array}$ & 3.5292 & .67998 & & \\
\hline
\end{tabular}




\begin{tabular}{|c|c|c|c|c|}
\hline Native speakers & 3.3458 & .77187 & & \\
\hline Familiarity & & & $-3.493 *$ & .001 \\
\hline $\begin{array}{l}\text { Non-native } \\
\text { speakers }\end{array}$ & 3.5979 & .88064 & & \\
\hline Native speakers & 3.2625 & .78580 & & \\
\hline Fluency & & & -1.249 & .214 \\
\hline $\begin{array}{l}\text { Non-native } \\
\text { speakers }\end{array}$ & 3.5236 & .05511 & & \\
\hline Native speakers & 3.4500 & .07233 & & \\
\hline Sophisticated & & & -.332 & .740 \\
\hline $\begin{array}{l}\text { Non-native } \\
\text { speakers }\end{array}$ & 3.4167 & .63868 & & \\
\hline Native speakers & 3.3958 & .75285 & & \\
\hline
\end{tabular}

\subsection{Familiarity with Native and Non-Native Varieties of English Accents}

In order to obtain information on the extent to which the Malaysian university students were able to distinguish between native and non-native accents of the six lecturers, as well as to what extent they were familiar with these accents, the students were asked to identify the accent of each speaker immediately after they have listened to the speech recordings. The percentages of the participants who identified each accent of the speakers correctly or incorrectly are shown in Table 3. The results indicated that the students were able to distinguish between native and non-native accents in the use of English. In terms of a hierarchy of scores, the data evidenced that Malay accented English (94.1\%) scored the highest followed by Indian (93.3 \%), Arabic (88.3\%) and lastly Chinese (87.5\%). However, the percentages of correct identification of native accents were relatively lower: American (75.8\%) > and British (65.0\%) (See Table 5). These results are consistent with Kim's (2007) study which indicated that the majority of the Korean university students were able to distinguish between native and non-native accents but they identified the non-native accents more correctly than the native accents.

Quite a number of the Malaysian students misidentified British accent as American accent and vice versa. The results of the present study reflect those of Chiba, Matsuura, and Yamamoto's (1995) study, where the Japanese university students had difficulties identifying whether the speaker was American or British. Kim's (2007) study also indicated that some of the Korean university students were confused between British and American accents.

Table 5. Percentage (\%) of accent identification $(n=120)$

\begin{tabular}{lcc}
\hline \multicolumn{1}{c}{ Speakers } & Frequency & Percent \\
Malay lecturer & 113 & 94.1 \\
Indian lecturer & 112 & 93.3 \\
Arabic lecturer & 106 & 88.3 \\
Chinese lecturer & 105 & 87.5 \\
American lecturer & 91 & 75.8 \\
British lecturer & 78 & 65.0 \\
\hline
\end{tabular}

The above results may come from the fact that non-native accents are usually used during lectures, public places, and at home. In other words, since Malaysia is a relatively ESL dominant country, the students normally have many opportunities to hear Malaysian English varieties of accent. Moreover, the students did not face any difficulties identifying the Iraqi accent because nowadays many Iraqis come to Malaysia either to work or to pursue their studies at Malaysian universities. So, the students are quite familiar with the Iraqi accent although some, especially the Chinese students, did mention to the researchers that it was difficult to understand the accent.

On the other hand, the students were confused between the British and American accent probably because they did not have many opportunities to listen to them in natural environments, such as having a British or an American friend. They are likely exposed to the accents just from watching movies or in other limited ways.

Therefore, it is quite expected that the students can easily identify the non-native accents but appeared quite confused by the British and American accents as a result of constrained exposure to the languages. This is further supported by Chiba, Matsuura, and Yamamoto's (1995) study which indicated that Japanese university students responded more positively to American and British accents than to the non-native accents such as the Japanese accent because they were more familiar with native accent compared to the non-native accents. It was found that the students were well-exposed to British and American English taped materials used as instructional models in classroom. Thus, when the Japanese students were asked to identify the accents, they were able to identify the native accents more correctly than the nonnative accents. 


\section{Conclusion}

This study was conducted to investigate Malaysian students' attitudes towards six varieties of accented speech delivered by both native and non-native speakers American, Arabic, British, Chinese, Malay, and Indian. The modified version of the "matched-guise technique" which is the "verbal guise technique" was adopted to record accented speech of the six lecturers. Also, a questionnaire was adapted for use from previous language attitude studies. One hundred and twenty Malaysian undergraduate students from Putra University of Malaysia participated in this study.

The results of this study indicate social characterization towards accented English language use among Malaysian students. There is a bias towards in-group preference and they evaluated the non-native lecturers' accents more positively than the native lecturers' accents based on eight different traits which cover clarity, solidarity, confidence, intelligence, being careful, fluency, familiarity, and sophisticated traits. By and large, the results supported the "social identity theory" that was developed by Tajfel and Turner in (1979, 1986). Also, these results were consistent with many previous studies that were conducted in the field (such as Abrams and Hogg, 1987; Bresnahan, Ohashi, Nebashi, Liu, and Shearman, 2002). Additionally, the results indicated that the Malaysian students were able to distinguish between native and non-native accents in the use of English although quite a number of them tended to have difficulties distinguishing between British or American accent.

Overall, the results of this study offer a clear picture of the Malaysian university students' attitudes toward six varieties of English accent. With a borderless world, it would be logical to extend such studies to English whose accents are Canadian, Australian, New Zealand, German, Russian, Iranian, or French for evaluation. As the slant is for non-native accented speech when using English, it calls for greater sensitivity to local accent in the use of the English language especially when in instruction. As part of an attempt to globalize and internationalize education in Malaysia, foreign lecturers are now a regular feature of the teaching instructors in many Malaysian educational institutions. A preference for the local accent conveys a direction of learning style among Malaysians. Therefore, knowing the learning style of Malaysians, in particular with reference to accent preference, instructors could then accommodate this feature in their teaching style.

The second part of the study affirms that local speech accent in the use of English is easily identifiable (showing a correctness score for recognition of more than 80\%). However, it was found that American accented English is more familiar than the British. This likely shows the widespread use of American English over British English in Malaysia. In effect, there appears a cultural shift contact in so far as accent familiarity is concerned. The pivotal influence of British English is losing ground and a firm sense of 'localness' in accent is preferred, and this is likely to be entrenched in tandem with a growing and keen consciousness of local pride in an ESL/EFL environment.

\section{References}

Abrams, D., \& Hogg, M.A. (1987). Language attitudes, frames of reference, and social identity: A Scottish dimension. Language and Social Psychology, 6, 201-213.

Alford, R.L., \& Strother, J.B. (1990).Attitudes of native and non-native speakers toward selected regional accents of U.S English. TESOL Quarterly, 24(3), 479-495.

Bex, T., \& Watts, R.J. (1999). Standard English: The widening debate. London: Routlege.

Butler, Y.G. (2003). Perception versus reality: how important is it that Korean elementary school teachers speak "Good English". World Papers in Educational Linguistics, 19, 1-25.

Bresnahan, M.J., R.Ohashi, R. Nebashi, W.Y. Liu, and S.M. Shearman. ( 2002). Attitudinal and affective response toward accented English. Language and Communication, 22,171-185.

Bresnahan, M.I., \& Kim, M.S. (1993).Factors of receptivity and resistance toward international teaching assistance. Journal of Asian Pacific Communication, 4, 1-12.

Cargile, A.C. (2000). Evaluations of employment suitability: Does accent always matter. Employment Counseling, 37 , 165-176.

Cargile, A.C., \& Giles, H. (1998). Language attitudes toward varieties of English: An American-Japanese context. Applied Communication Research, 26, 338-356.

Cargile, A.C., Takai, J., \& Rodriguez, J.I. (2006). Attitudes toward African-American vernacular English: A U.S export to Japan. Journal of Multilingual and Multicultural development 27,443-456.

Creber, C. \& Giles, H. (1983).Social context and language attitudes: The role of formality-informality of the setting. Language Sciences, 5, 155-162.

Cheyne, W.M. (1970). Stereotyped reactions to speakers with Scottish and English regional accents. British Journal of Social and Clinical Psychology, 9, 77-79.

Chiba, R., Matsuura, H. \& Yamamoto, A. (1995). Japanese attitudes toward English accents. World Englishes, 14, 7786.

Fishman, J.A. (1971). Sociolinguistics: A brief introduction. Boston: Rowley. 
Fought, C. (2002). California students' perceptions of, you know, regions and dialects?.In D. Long, \& D. Preston, D. (Eds.), A Handbook of Perceptual Dialectology, vol.2. (pp.113-34). Amesterdam: Benjamins.

Giles, H. (1971). Patterns of evaluation in reactions to RP, South Welsh and Somerset accented speech. British journal of Social and Clinical Psychology, 10, 280-281.

Giles, H. (1970). Evaluative reactions to accents. Educational review, 22, 211-227.

Giles, H., \& Billings, A.C. (2005). Assessing language attitudes: Speaker evaluation studies. In A. Davies, \& C. Elder (Eds.), The handbook of Applied Linguistics (pp.187-209).Oxford: Blackwell.

Giles, H., and N. Coupland. 1991. Language, contexts, and consequences. Milton Keynes: Open University Press.

Giles, H., Hewstone, M., Ryan, E.B., \& Johnson, P. (1987). Research on language attitudes. In H. Ammon, N. Dittmmar, \& J. K. Mattheier (Eds.), Sociolinguistics (pp.585-597). Berlin: Walter de Gruyter.

Giles, H., \& Powesland, P.F. (1975).Speech style and social evaluation. New York: Academic Press.

Gill, S.K. (2002). International communication: English language challenges for Malaysia. Selangor: Putra University of Malaysia Press.

Gill, S.K. (1999). Standards and emerging linguistic realities in the Malaysian workplace. World Englishes, 18, 215231.

Garrett, P., Coupland, N. \& Williams, A. (2003). Investigating language attitudes: Social meaning of dialect, ethnicity and performance. Cardiff: University of Wales Press.

Grondelaers, S., Hout, R.V., \& Steegs, M. (2010). Evaluating regional accent in Standard Dutch. Language and Social Psychology, 29 (1), 101-116.

Hiraga, Y. (2005). British attitudes towards six varieties of English in the USA and Britain. World Englishes, 24,289308.

Holmes, J. (1992). An introduction to sociolinguistics. New York: Longman.

Hughes, A., \& Trudgill, P. (2003). English accents and dialects. $3^{\text {rd }}$ ed. Arnold: London.

Kim, Y.S. (2007). Korean Attitude towards Varieties of English. MSc Thesis., University of Edinburgh.

Lippi-Green, R. (1997).English with an accent: Language ideology and discrimination in the United States. London: Routledge.

Lindemann, S. (2003). Korean, Chinese or Indians? Attitudes and ideologies about non-native English speakers in the United States. Journal of Sociolinguistics, 7, 348-364.

Matsuura, H., Chiba, R., \& Fujieda, M. (1999). Intelligibility and comprehensibility of American and Irish Englishes in Japan. World Englishes18 (1), 49-62.

Matsuura, H., Chiba, R., \& Yamamoto, A. (1994). Japanese college students' attitudes towards non-native varieties of English. In D. Graddol, and J. Swan (Eds.) Evaluating language (pp.52-61). Clevedon: BAAL/ Multilingual Matters.

McKenzie, R.M. (2010). Social psychology of English as a global language. Dordrecht: Springer.

McKenzie, R.M. (2008). Social factors and non-native attitudes towards varieties of spoken English: A Japanese case study. International Journal of Applied Linguistics 18 (1), 64-88.

Milroy, L. (2001) .The social categories of race and class: language ideology and sociolinguistics. In N. Coupland, S. Sarangi, \& C.N. Candlin (Eds.), Sociolinguistics and Social Theory (PP.16-39). London: Rutledge.

Nelson, G.L. (1991). Effective teaching behaviour for international teaching assistants. In J.D. Nyquist, R.D. Abbott, D.H. Wulff, \& J. Sprague (Eds.), Preparing the professoriate of tomorrow to teach (pp.427-434). Dubuque, IA: Kendall Hunt.

Nyquist, J.D., Abbott, R.D., Wulff, D.H., \& Sprague, J. (Eds.) (1999). Preparing the professoriate of tomorrow to teach (pp.427-434). Dubuque, IA: Kendall Hunt.

Pillai, S. (2009). A study of the use of English among undergraduates in Malaysia and Singapore. SARE 1, 1-28.

Pillai, S. (2008). Speaking English the Malaysian way- correct or not. English Today 96, 24 (4), 42-45.

Reinard, J.C. (2006). Communication research statistics. California, United States: Sage Publications.

Richards, J., Platt, J., \& Platt, H. (1992). Longman dictionary of applied linguistics3rd edition. Harlow: Longman.

Ryan, E.B. (1983). Social psychological mechanisms underlying native speaker reactions to nonnative speech. Studies in Second Language Acquisition, 5,148-159.

Ryan, E.B., \& Bulik ,C.M.(1982). Evaluations of middle class and lower class speakers of standard American and German-accented English. Language and Social Psychology, 1, 51-61.

Ryan, E.B., \& Giles, H. (1982). Attitudes towards language variation: Social and applied contexts. Edward Arnold.

Ryan, E.B., Hewstone, M., \& Giles, H. (1984). Language and intergroup attitudes. In J. Eiser (Eds.), Attitudinal Judgment (pp.135-160).New York: Springer. 
Starks, D. \& Paltridge, B. (1996). A note on using sociolinguistic methods to study non-native attitudes towards English. World Englishes, 15, 217-224.

Solomon, B.B. (1999). Teaching an increasingly diverse undergraduate population. In J.D. Nyquist, R.D.Abbott, D.H. Wulff, \& J. Sprague (Eds.), Preparing the professoriate of tomorrow to teach (pp.55-64). Dubuque, IA: Kendall Hunt.

Tajfel, H., \& Turner, J. (1986). The social identity theory of intergroup behaviour. In S. Worchel \& W. Austin (Eds.), Psychology of intergroup relations (pp.7-24). Austin. Chicago, United States: Nelson-Hall.

Tajfel , H., \& Turner, J. (1979). An investigative theory of intergroup conflict. In S. Worchel \& W. Austin (Eds.), The social psychology of intergroup relations (pp.33-47).California: Brooks/Cole, Monterey.

Van Bezooijen, R., \& Gooskens, C. (1997). Identification of language varieties: The contribution of different linguistic levels. Language and Social Psychology, 18, 31-48.

White, M.J., \& Li, Y. (1991). Second-language fluency and person perception in China and the United States. Language and Social Psychology, 10, 99-113.

Wilson, J. \& Bayard, D. (1992).Accents, gender, and the elderly listener: evaluations of NZE and other English accents by rest home residents. Te Reo, 35, 19-56.

Zahn, C.J., \& Hopper, R. (1985). Measuring language attitudes: The speech evaluation instrument. Language and Social Psychology, 4, 113-123. 